\title{
Prize Awards for 1935 of the Paris Academy of Sciences
}

$\mathrm{A}^{\mathrm{T}}$ $\Gamma$ the public annual meeting of the Paris Academy of Sciences on December 16, the prizes and grants for the year 1935 were announced as follows:

Mathematics.-The Francœur Prize to André Weil, for his work in algebra.

Mechanics.-The Montyon Prize to Pierre Dupin, for his work on the mechanics of fluids ; the Poncelet Prize to Auguste Lafay, for the whole of his work in mechanies; the Henri Bazin Foundation to Adrien Foch, for his experimental researches in hydraulics.

Astronomy.-The Lalande Prize to Lucien d'Azambuja, for the whole of his work; the Damoiseau Prize, in equal parts, between Guy Reiss and André Patry, for the whole of their work; the Benjamin Valz Prize to Raymond Tremblot, for the whole of his work; the Pierre Guzman Prize, in equal parts, between. Jules Baillaud, André Danjon and Armand Lambert, for the whole of their work; the G. de Pontécoulant Prize to Georges Durand, for the whole of his work; the La Caille Prize to Raoul Goudey, for his studies relating to the intensity of gravity.

Geography. - The Gay Prize to Louis Feyler, for his exploration in the Tchad Ténéré; the Tchihatchef Foundation to Edmond Saurin, for an important study on the stratigraphy and tectonics of the south of Annam; the Alexandre Givry Prize to Joseph Volmat, for his exploratory work on the coasts of France and the application of aerial photography to hydrographic surveys.

Navigation.-The Ministère de la Marine Prize to André Pommelet, for his work on naval construction; the Plumey Prize to Marcel Rouchet, for his work relating to the fatigue of metals.

Physics.-The Gaston Planté Prize to Marcel Pauthenier, for his work in the field of electricity; the Hébert Prize to Jean Fallou, for his work in electricity, especially for his book "Les réseaux de transmission d'énergie "; the Henri de Parville Prize to Jean Mercier, for his work on electric oscillations; the Hughes Prize to Louis Néel, for his work on magnetism; the Pierson-Perrin Prize to Pierre Auger, for the whole of his work ; the Clément Félix Foundation to Charles Dietsch, for the continuation of researches on continuous eurrents of great intensity.

Chemistry.-The Montyon Prize (Unhealthy Trades) between René Fabre (2,500 francs), for the whole of his work in toxicology, and Lucien Leroux $(1,500$ franes), for his work on arsenic ; the Jecker Prize to Marcel Godchot, for his work in organic chemistry; the Cahours Foundation to Félix Trombe, for his researches on the isolation of the rare earths in the metallic state; the Houzeau Prize to Edmond Vellinger, for numerous physico-chemical measurements on organic compounds and biological substances.

Mineralogy and Geology.--The Delesse Prize to Antonin Lanquine, for his geological work in Provence; the Fontannes Prize to Jean Viret, for his work on the palæontology of the vertebrates; the Victor Raulin Prize to Georges Lecointre, for his geological work on Morocco and Touraine; the Joseph Labbé Prize to Louis Glangeaud, for his geological work.
Botany.-The Desmazières Prize to Pierre Dangeard, for his "Traite d'Algologie" ; the Montagne Prize to Charles Killian, for his work as a whole; the Jean Thore Prize to Robert Douin, for his contribution to the "Flore illustré de France"; the de Coincy Prize to Marie-Victorin, for his "Flore Laurentienne" ; the Jean de Ruez de Lavison Prize to Robert Echevin, for his work relating to the metabolism of nitrogen, phosphorus and sulphur in the dead leaves of ligneous plants.

Rural Economy.-The Paul Marguerite de la Charlonie Prize to Albert Demolon, for his researches on the chemistry of soils.

Anatomy and Zoology.-.-The Cuvier Prize to Paul Marais de Beauchamp, for his varied researches on the invertebrates; the Savigny Foundation to Marc André, for the continuation of work on the Arachnids.

Medicine and Surgery.-Montyon Prizes to Antoine Catanei (2,500 francs), for his studies on mycoses, Stefan Nicolau (2,500 francs), for his work on hydrophobia, Michel Salmon and Jacques Dor $(2,500$ franes), for their book "Artères des muscles, des membres et du trone"; honourable mentions (1,500 francs) to Germaine Amoreux, René Lançon and Seymour Nemours-Auguste; citations to Raoul Palmer, Pierre Princeteau and Henri Fischer, and to Pierre Uhry; the Barbier Prize to René Moricard, for his memoir "Proliférine sexuelle femelle. Contri. bution à l'étude de la fonction de la folliculine" ; the Bréant Prize to Serge Metalnikov, for his memoir on the role of the nervous system and of the biological and physical factors in immunity ; the Godard Prize to Robert Raynaud, for his book on the functional antagonism between the ovarian hormones and the mechanism of folliculinic abortion; the Chaussier Prize between Henri Bierry and Francis Rathery $(8,000$ francs), for their introduction to the physiology of the sugars, and Léon Dérobert, for his work entitled "De la carbonisation de la peau et de ses annexes (poils, ongles et dents)"; the Mège Prize to Louis Chauvois, for his book on the circulation of the blood; the Bellion Prize to Mare Klein, for his memoir on the yellow body in pregnancy; the Baron Larrey Prize to Robert Tournier-Lassorve, for his memoir on the health service of the army ; the Jean Dagnan-Bouveret Prize, in equal parts, between René Ledoux-Lebard, for his manual of clinical radiodiagnosis, and Pierre Duval, Jean Charles Roux and Henri Béclère, for their memoir on the clinical radiology of the alimentary canal.

Cancer and Tuberculosis.-The Roy-Vaucouloux Foundation to Jean Loiseleur, for his researches on biological physics and chemistry and their applica. tion to the study of cancer; the Louise Darracq Prize between Albert Peyron (3,000 francs), for the whole of his work on cancer, Jean Montpellier $(1,500$ franes $)$, for his work on tumours, and Georges Piraud (1,500 franes), for his book on the notochord and its tumours; the Henriette Rógnier Foundation to Roger Laporte, for his work on tuberculosis.

Physiology.- The Montyon Prize to Antoine Jullien, for his physiological researches and his book on practical physiology; the Pourat Prize to Jules 
Carles; the Philipeaux Prize to Serge Tchakhotine, for his studies on the methods and problems of cellular microexperimentation.

Statistics.-The Montyon Prize to Robert Gibrat, for his work in mathematical statistics.

History and Philosophy of the Sciences.-The Binoux Prize to George Sarton, for his three volumes, "Introduction to the History of Science, up to the time of Roger Bacon". A prize of 1,000 franes to Henri L. Brugmans, for his book, "Le séjour de Christian Huygens à Paris suivi de son Journal de voyage à Paris et à Londres".

Works of Science.-The Henri de Parville Prize between Jean Villey, for his publications on applied thermodynamics, and Georges Darmois, for his book on statistics and its applications; the Jules and Louis Jeanbernat et Barthelemy de Ferrari Doria Prize to Marcel Abeloos, for his book on regeneration and the problems of morphogenesis.

Medals.--The Berthelot Medals to René Fabre and Edmond Vellinger.

General Prizes.-The Prize founded by the State to Auguste Loubière, for his researches in the comparative anatomy of plants and in palæobotany; the Bordin Prize to Henri Cartan, for his work in mathematical analysis: the Lallemand Prize to Pierre Mollaret, for his researches on Friedreich's disease and its homologue in the dog; the Serres Prize to Paul Wintrebert, for his work in embryology; the Maujean Prize to Maurice Edme Courtois Suffit and Edouard Zedet, for their book "Lutte contre les intoxications dans la fabrication des poudres et explosifs"; the Petit d'Ormoy Prize (Mathematical Sciences) to Maurice Fréchet, for the whole of his mathematical work; the Petit d'Ormoy Prize (Natural Sciences) to René Maire, for his work on the flora of northern Africa; the Saintour Prize to Jean Jacques Trillat, for his work on the application of X-rays and electronic diffraction to the study of the structure of organic materials; the Lonchampt Prize to Augustin Damiens, for his work on bromine in animals and plants; the Henry Wilde Prize to Paul Bertrand, Pierre Pruvost, Paul Corsin and Gérard Waterlot, for their study of the coal formations of the Sarre and Lorraine; the Gustave Roux Prize to Henri Nouvel, for his researches on the eytology, physiology and biology of the Dicyemidx; the Thorlet Prize to Paul Dorveaux ; the Marquet Prize to Pierre Chevenard, for his metallurgical researches.

Prizes of the Grandes Ecoles.-The Laplace Prize to Francois Mialaret; the L. E. Rivot Prize to François Mialaret, Albert Denis, Jean Courbon and Jacques Boué.

General Foundations for Scientific Researches.-The Hirn Foundation to Georges Giraud. for his mathematical work; the Henri Becquerel Foundation to Mlle. Yvette Cauchois, for her researches on the spectrography of the $\mathrm{X}$ - and $\gamma$-rays; the Mme. Victor Noury Foundation to Jean Delsarte $(3,000$ francs), for his work in mathematical analysis, Jean Wyart (2,500 francs), for his work on the constitution of the zeolites, Ferdinand Angel (2,000 francs), for his description of the herpetological fauna of western Africa, Georges Deflandre (2,000 franes), for his work on the Protists, especially the Flagellates, preserved in flint, Jean Lecomte (2,000 francs), for his researches on the infra-red spectrum; the Charles Frémont Foundation to André Paillot, for his work in applied entomology ; the Lannelongue Foundation to Mme. Gabriel Cusco.

\section{ThE LOUTREUIL Foundation}

The Academy has considered forty-three applications for grants from this fund and has allocated awards as follows:

(1) Researches on Fixed Problems.--Pierre Viala and Paul Marsais (2,000 francs), for the study of the best methods for combatting the enemies of the vine, especially mildew ; Maurice Pierre (3,000 franes), for researches on the mechanism of vomiting; Armand Tapernoux and Robert Vuillaume (2,000 francs), for their work on diastatic hydrolysis in the organism, the active principles of linseed cake and on the action of amines in the organism ; Jean Sendrail and Robert Lasserre (3,000 francs), for the study of castration in Solipods; Charles Hervieux (3,000 francs), for his researches on the passage into sweat of indoxylic chromogens, resulting from putrefaction in the intestine in domestic animals; James Dantzer $(2,000$ franes), for his study of elasticity and tests for wear in textile threads; André Aron (2,000 franes), for his researches on thin metallic films; Vladimir Frolow (2,000 francs), for his hydrological researches in the valley of the Loire; Pierre Jolibois $(5,000$ francs), for his studies on the electrolysis of saline solutions under high electromotive forces; Raoul Lecoq (2,000 francs), for his researches on vitamins ; Louis Leprince-Ringuet and Pierre Auger $(5,000$ franes), for their studies of cosmic rays carried out at the Jungfraujoch Observatory; Pierre Allorge (10,000 francs), as a contribution to an expedition to the French Antilles for the study of Cryptogams in these islands ; George Waterlot (3,000 francs), for prehistoric and ethnographic studies in Mauritania, Senegal, French Sudan, French and Portuguese Guinea.

(2) The Purchase of Laboratory Material.-Léon Guillet (4,000 francs), for the purchase of a micromachine for tests on the strength of materials; Institut national agronomique (7,000 franes), for the erection of a greenhouse; Casimir Monteil $(5,000$ francs), for the purchase of a Diesel motor ; Pierre Fremy (5,000 franes), to complete the laboratory material for his researches on Algæ; André Paillot (4,000 francs), for procuring microscopical apparatus necessary for his researches on the normal and pathological histology and anatomy of insocts.

(3) Publications.-Fédération française des Sociétés de sciences naturelles (5,000 franes), as a contribution to the publication of the "Faune de France"; Joseph Monestier (3,000 franes), for printing a memoir on Ammonites; Remy Perrier (3,000 francs), for assisting the publication of his "Faune de France" with illustrated synoptic tables; Mare Simonet $(2,000$ francs $)$, for the reproduction in water colour of a collection of Iris ; Société des Amis d'André Marie Ampère (4,000 francs), for assisting the publication of the journal and correspondence of Ampère on the occasion of his centenary ; Comité de Physique du Globe des colonies (10,000 francs), for the publication of the "Annales de Physique du Globe de la France d'outre-mer".

(4) Grants to Libraries.--Ecole Polytechnique $(6,000$ francs), Ecole nationale vétérinaire d'Alfort (6,000 francs), Ecole nationale vétérinaire de Lyon (3,000 francs), Institut national agronomique $(3,000$ francs), Société française des Electriciens $(1,000$ francs). 